\title{
Characterization of aquabirnaviruses from flounder Pseudopleuronectes americanus and mummichog Fundulus heteroclitus in the Chesapeake Bay, Virginia, USA
}

\author{
W. Ahne ${ }^{1}$, S. Blake ${ }^{3}$, S. Essbauer ${ }^{2, *}$, B. L. Nicholson ${ }^{3}$ \\ ${ }^{1}$ Institute of Zoology, Fisheries Biology and Fish Diseases, and ${ }^{2}$ Institute of Medical Microbiology, \\ Infectious and Epidemic Diseases, Ludwig Maximilians University of Munich, 80539 Munich, Germany \\ ${ }^{3}$ Department of Biochemistry, Microbiology and Molecular Biology, University of Maine, Orono, Maine 04469, USA
}

\begin{abstract}
Viruses were isolated in cell culture from tissue homogenates of flounder Pseudopleuronectes americanus and mummichog Fundulus heteroclitus in the Chesapeake Bay, Virginia, USA. Neutralization and immunofluorescence tests with aquabirnavirus (West Buxton strain)-specific polyclonal antisera indicated that both viruses were aquabirnaviruses belonging to Serogroup A, the most common aquabirnavirus serogroup in the United States. This was confirmed by RT-PCR, with primers targeting the VP3 and VP2 gene of aquabirnaviruses. The VP2-specific RT-PCR cDNA amplification product was sequenced and deduced amino-acid sequences were compared with known sequences of the type strains of the 9 serotypes of aquabirnavirus Serogroup A. This demonstrated that the viruses from both flounder and mummichog belong to aquabirnavirus Genogroup 1. The flounder isolate exhibited deduced amino acid sequence similarities of $98.1 \%$ with the Jasper strain of serotype A9, and $97.7 \%$ with the West Buxton strain of serotype A1. The isolate from mummichog exhibited deduced amino acid sequence similarities of $99.1 \%$ with the West Buxton strain of Serotype A1 and $94.8 \%$ with the Jasper isolate of Serotype A9. Similarities of deduced amino acid sequences ranged from 79.9 to $86.9 \%$, with representatives of the other 7 serotypes. This is the first report of an aquabirnavirus from mummichog $F$. heteroclitus and only the fifth report of an aquabirnavirus from a flounder species.
\end{abstract}

KEY WORDS: Aquabirnavirus · Flounder · Mummichog Resale or republication not permitted without written consent of the publisher

\section{INTRODUCTION}

Aquabirnaviruses are characterized by an unenveloped, icosahedral capsid approximately $60 \mathrm{~nm}$ in diameter, containing a bisegmented, double-stranded RNA genome (Cohen et al. 1973, MacDonald \& Yamamoto 1977, Dobos et al. 1979, Dobos \& Roberts 1983). The smaller genome segment (2784 bp) has one overlapping reading frame (ORF) which encodes the internal virion-associated RNA-dependent RNA polymerase VP1 $(94 \mathrm{kDa})$. Genome Segment A (approximately $3100 \mathrm{bp}$ ) contains 2 partial ORFs (Duncan et al. 1987, Havarstein et al. 1990). The large ORF encodes the major capsid protein, VP2; VP3, a minor capsid protein; and NS, a non-structural protein. The coding order for these polypeptides within the genome Segment $\mathrm{A}$ is $\mathrm{NH}_{2}$-VP2-NS-VP3-COOH. The small ORF encodes a $17 \mathrm{kDa}$ arginine-rich minor polypeptide, designated VP5, for which no function has been identified.

The vast majority of aquabirnaviruses, regardless of host species or geographic origin, are related antigenically and form a major serogroup (Serogroup A) (Caswell-Reno et al. 1989, Christie et al. 1990, Nicholson 1993, Hill \& Way 1995). A few antigenically unrelated aquabirnaviruses represent a second, minor 
serogroup (Serogroup B). Based on reciprocal neutralization tests with polyclonal antisera and enzyme immunoassays with monoclonal antibodies, Serogroup A contains 9 cross-reacting serotypes: A1 (Type Strain West Buxton, WB), A2 (Type Strain Sp), A3 (Type Strain Ab), A4 (Type Strain He), A5 (Type Strain Te), A6 (Type Strain Canada 1), A7 (Type Strain Canada 2), A8 (Type Strain Canada 3), and A9 (Type Strain Jasper-ATCC VR 1325). Most aquabirnavirus isolates from freshwater and marine fish in the United States belong to the A1 serotype. Four serotypes (A6, A7, A8, and A9) occur in Canada, and 4 serotypes (A2, A3, A4, and A5) are found in Europe. Isolates representing Serotypes A1, A2, and A3 have been found in Asia and South America.

A recent investigation of the genomic relationships of a large number of aquabirnaviruses from a variety of geographical areas worldwide demonstrated that these viruses represent at least 6 major genogroups (Blake et al. 2001). Furthermore, these genogroups generally correlate with geographical origin and previous serological classifications of these viruses, based on reaction with polyclonal and monoclonal antibodies. It is now possible to rapidly identify the genogroup and, possibly, serotype of a new aquabirnavirus isolate using reverse transcriptase polymerase chain reaction (RT-PCR), sequencing the amplified CDNA, and comparing this nucleotide sequence with the sequence database of genome Segment A.

The aquabirnaviruses are the largest and most diverse group of viruses within the family Birnaviridae. Many of these viruses have been proven or implicated as the etiologic agents of disease in a variety of fish species, important in fish farming and aquaculture worldwide (Wolf 1988). Aquabirnaviruses have also been isolated from a variety of teleost fish, molluscs and crustacea in freshwater, estuarine and marine environments (Hill 1982, Essbauer \& Ahne 2001). Aquabirnaviruses have been shown to be present in a variety of wild marine fish species, including Atlantic menhaden Brevoortia tyrannus (Stephens et al. 1980); sea bass Dicentrarchus labrax, turbot Scophthalmus maximus, Dover sole Solea solea, (Hill 1982); hogchocker Trinectes maculatus, Atlantic silverside Menidia menidia, spot Leiostomus xanthurus, Atlantic croaker Micropogon undulatus, silver perch Bairdiella chrysura, striped mullet Mugil cephalus (McAllister et al. 1984); Atlantic salmon Salmo salar (Christie et al. 1988); and yellowtail Seriola quinqueradiata (Sorimachi \& Hara 1985, Kusuda et al. 1989). Aquatic birnaviruses have been isolated from a variety of flounder species: Paralychthys olivaceus (Sano \& Fukuda 1987, Sohn et al. 1995); P. lethostigma (McAllister et al. 1984); P. flesus (Mortensen et al. 1999) and greenback flounder Rhombosolea tapirina (Munday \& Owens 1998).
In this paper, we describe the isolation and identification of aquabirnaviruses from 2 previously unreported teleost hosts in the Chesapeake Bay, Virginia, USA. Viruses were isolated from flounder Pseudopleuronectes americanus and mummichog Fundulus heteroclitus.

\section{MATERIALS AND METHODS}

Virus isolation and identification. Rainbow trout gonad cells (RTG- $2_{2}$ cells) (Wolf \& Quimby 1962) were propagated in Eagle's minimum essential medium (MEM) supplemented with $10 \%$ fetal bovine serum and antibiotics (100 IU ml ${ }^{-1}$ penicillin, $100 \mathrm{\mu g} \mathrm{ml}^{-1}$ streptomycin) at $20^{\circ} \mathrm{C}$. Pools of internal organs of mummichog and flounder collected from the Chesapeake Bay in Virginia were prepared for virus isolation by homogenization and filtration through a $200 \mathrm{~nm}$ (Millipore) filter. RTG-2 cells were inoculated with dilutions of the homogenates and incubated at $15^{\circ} \mathrm{C}$. Supernatants of cultures exhibiting cytopathic effects (CPE) were harvested for chloroform treatment and electron microscopy (negative staining) according to standard procedures (Mahy \& Kangro 1996). Serological identification of the isolated viruses was done by a neutralization test using standard methods with polyclonal infectious pancreatic necrosis virus (IPNV)-WB antiserum, and indirect immunofluorescence (IF) using the commercial BIO-FLOU IPN kit (Bio-X, Dilbeck). Viral RNA was isolated from infectious cell culture medium $\left(10^{9} \mathrm{TCID}_{50} \mathrm{ml}^{-1}\right)$ using the QIAmp viral RNA isolation kit (QIAGEN). First-strand cDNA was generated by the use of You-Prime First Strand Beads (Pharmacia-Biotech) in the RT-PCR. The primers for amplification were 5'-AAAGCCATAGCCGCCCATGAAC-3' and $5^{\prime}$-TCTCATCAGGTGGCCCAGGTAC-3' based on the genomic sequences of the VP3 coding region (2139 to $2312 \mathrm{bp}$ ) of the Jasper strain (Duncan \& Dobos 1986). RT-PCR was carried out in 35 cycles of denaturation at $94^{\circ} \mathrm{C}$ for $30 \mathrm{~s}$, annealing at $58^{\circ} \mathrm{C}$ for $30 \mathrm{~s}$ and extension at $72^{\circ} \mathrm{C}$ for $60 \mathrm{~s}$. PCR products were visualized after agarose gel electrophoresis using ethidium bromide and UV light.

cDNA sequencing and genotyping. An RT-PCR assay specific for the VP2 region of IPNV was carried out. Amplification conditions and sequencing of the PCR products were performed using the primers and procedures described previously (Blake et al. 2001). Sequences were edited using the Sequence Navigator (Applied Biosystems) Program. Deduced amino acid sequences were derived with the DNASTAR (Lasergene) EditSeq computer program. Multiple sequence alignments and calculation of amino acid sequence similarities were performed using the DNASTAR 

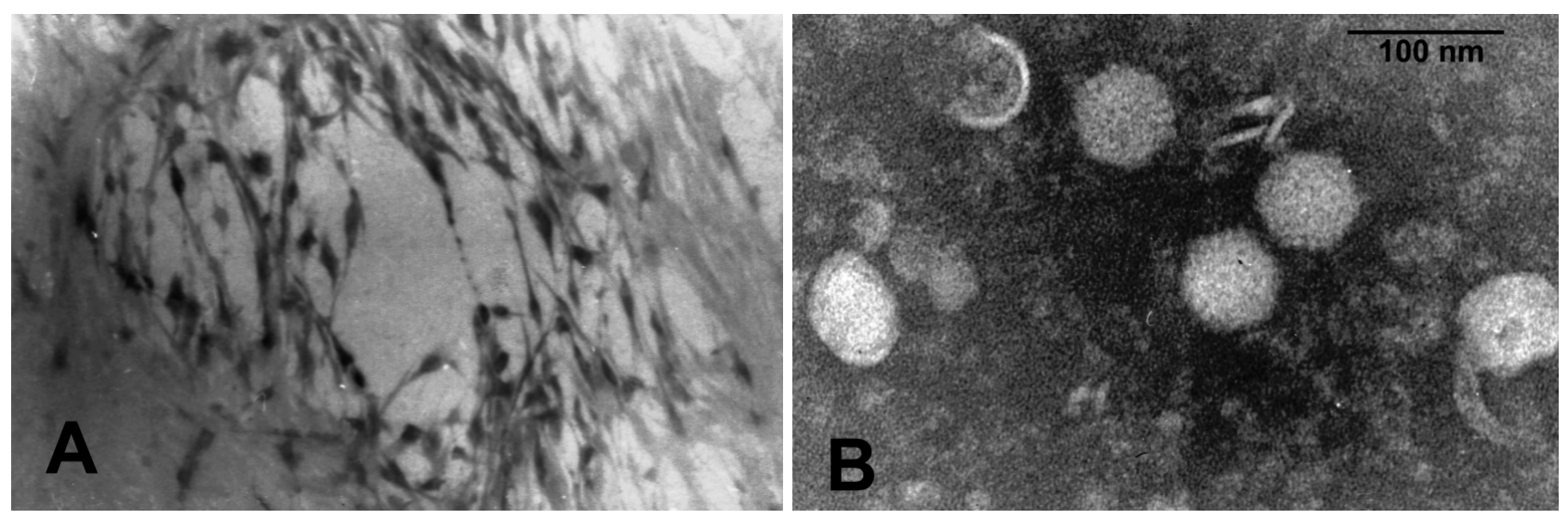

Fig. 1. (A) Rainbow trout gonad cells (RTG-2) cell lines exhibiting cytopathic effect $24 \mathrm{~h}$ after inoculation of mummichog tissue homogenate. (B) Electron micrograph of negatively stained infectious pancreatic necrosis virus isolated from mummichog in the Chesapeake Bay

MegAlign program with suggested parameters of Unweighted Gap penalty of 10, and Gap length penalty of 10. The nucleotide and deduced amino acid sequence data reported in this paper have been deposited in GenBank (birnavirus of flounder, Accession No. AY280454; birnavirus of mummichog, Accession No. AY280455).

\section{RESULTS}

After inoculation of tissue homogenates from asymptomatic flounder and mummichog, RTG-2 cell cultures exhibited CPE characterized by rounding up and lysis of cells for $24 \mathrm{~h}$ (Fig. 1A). Infectivity titers reached $10^{8.5-9} \mathrm{TCID}_{50} \mathrm{ml}^{-1}$. The isolated cytopathic agents son of these new isolates with each other (Fig. 4), and with the corresponding amino acid sequence of the type strains of the 9 serotypes of aquabirnavirus Serotype A (Table 1). The comparison of the deduced amino sequences demonstrated that the viruses from both flounder and mummichog belong to aquabirnavirus Genogroup 1 (Blake et al. 2001) (Table 1). The flounder isolate exhibited deduced amino acid similarities of $98.1 \%$ with the Jasper strain of Serotype A9, and $97.7 \%$ with the WB strain of Serotype A1. The isolate from mummichog exhibited deduced amino acid similarities of $99.1 \%$ with the WB strain of Serotype A1, and $94.8 \%$ with the Jasper isolate of Serotype A9. Similarities of deduced amino acid sequences ranged from 79.9 to $86.9 \%$ with representatives of the other 7 serotypes. proved to be ether stable. Electron micrographs of negatively stained preparations showed non-enveloped particles of icosahedral morphology, with a diameter of 55 to $60 \mathrm{~nm}$ (Fig. 1B).

Both viruses were neutralized by polyclonal antiserum prepared against the WB strain with neutralization titer indices of 5 to $6 \log _{10}$. Cells infected with the isolates revealed brilliant cytoplasmic fluorescence in the IF assay (Fig. 2). The RT-PCR with specific primers targeting the VP3 gene of aquabirnaviruses generated products of the expected size of 180 bp (Fig. 3).

The RT-PCR with specific primers targeting the VP2 gene resulted in $1281 \mathrm{bp}$ fragments (data not shown). A sequence of 427 sequences within the VP2 protein was chosen for compari-

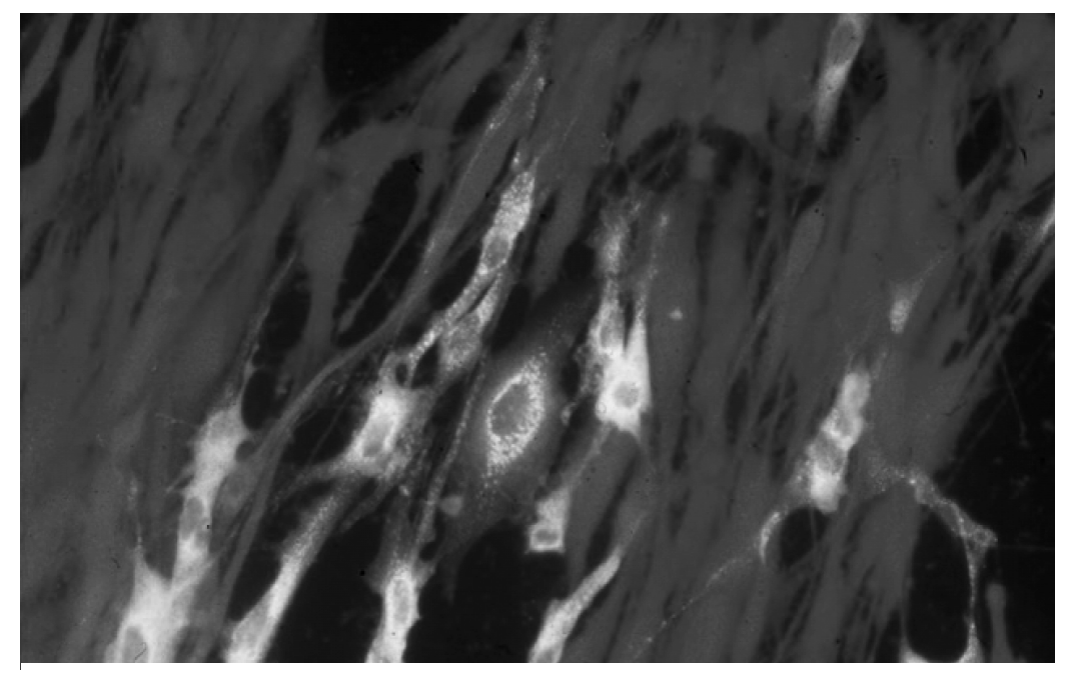

Fig. 2. Immunofluorescence of RTG-2 cells infected with the flounder Pseudopleuronectes americanus isolate ( $24 \mathrm{~h}$ post infection). Infected cells treated with a serum against infectious pancreatic necrosis virus strain West Buxton exhibit bright fluorescence in the cytoplasm 


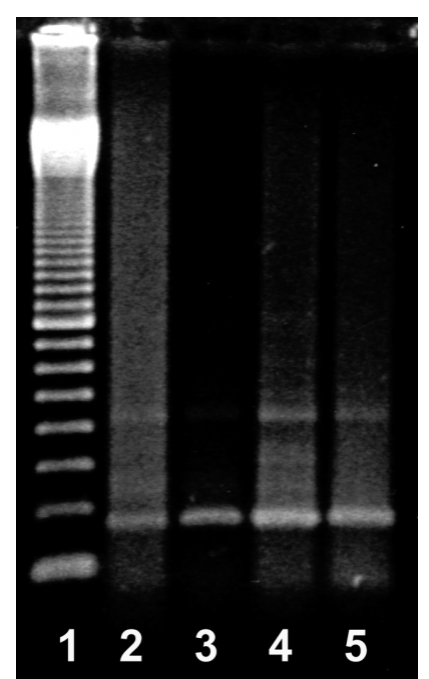

Fig. 3. Gel electrophoresis of RT-PCR products of viral RNA of aquabirnavirus isolates described in this study and the West Buxton and Jasper strains with primers targeting the VP3 region. Lane $1=100$ bp marker, Lane $2=$ West Buxton strain, Lane 3 = Jasper strain, Lane 4 = flounder Pseudopleuronectes americanus isolate, Lane $5=$ mummichog Fundulus heteroclitus isolate

\section{DISCUSSION}

In this study, we describe 2 viruses isolated from 2 marine fish species in the Chesapeake Bay, Virginia. Both viruses were identified as aquabirnaviruses based on their size and morphology in electron micro- graphs, neutralization and immunofluorescence with aquabirnavirus-specific antiserum, and RT-PCR with aquabirnavirus primers specific for the VP3 genomic coding regions. Further confirmation as aquabirnaviruses was obtained by RT-PCR with a different set of primers targeting the VP2 coding region.

The cDNA obtained from RT-PCR of the VP2 coding region of both viruses was sequenced, and the analyzed sequences of 427 amino acids within the VP2 protein of each virus were compared with each other, and with the amino acid sequences of the same region of the type strains of the 9 serotypes of Serogroup A. Based on these comparisons of deduced amino acid sequences, both viruses were found to belong to aquabirnavirus Genogroup 1 (Blake et al. 2001). Genogroup 1 comprises the aquabirnavirus strains representing Serotype A1 (West Buxton) and Serotype A9 (Jasper). The virus isolated from mummichog was found to be virtually identical $(99.1 \%$ similarity in amino acid sequence) to the WB strain (Table 1), a member of the most prevalent serotype (A1) in the United States. The virus isolated from flounder exhibited similarities in amino acid sequence of 98.1 and $97.7 \%$ with the Jasper and WB strains, respectively (Table 1). Both the WB and Jasper viruses belong to Genotype 4 within Genogroup 1 of aquabirnaviruses (Blake et al. 2001). These data suggest that the flounder isolate may belong to the Jasper serotype. However, it is not possible to definitively conclude this, since serotyping with polyclonal or monoclonal antibodies was not performed. It should also be noted that

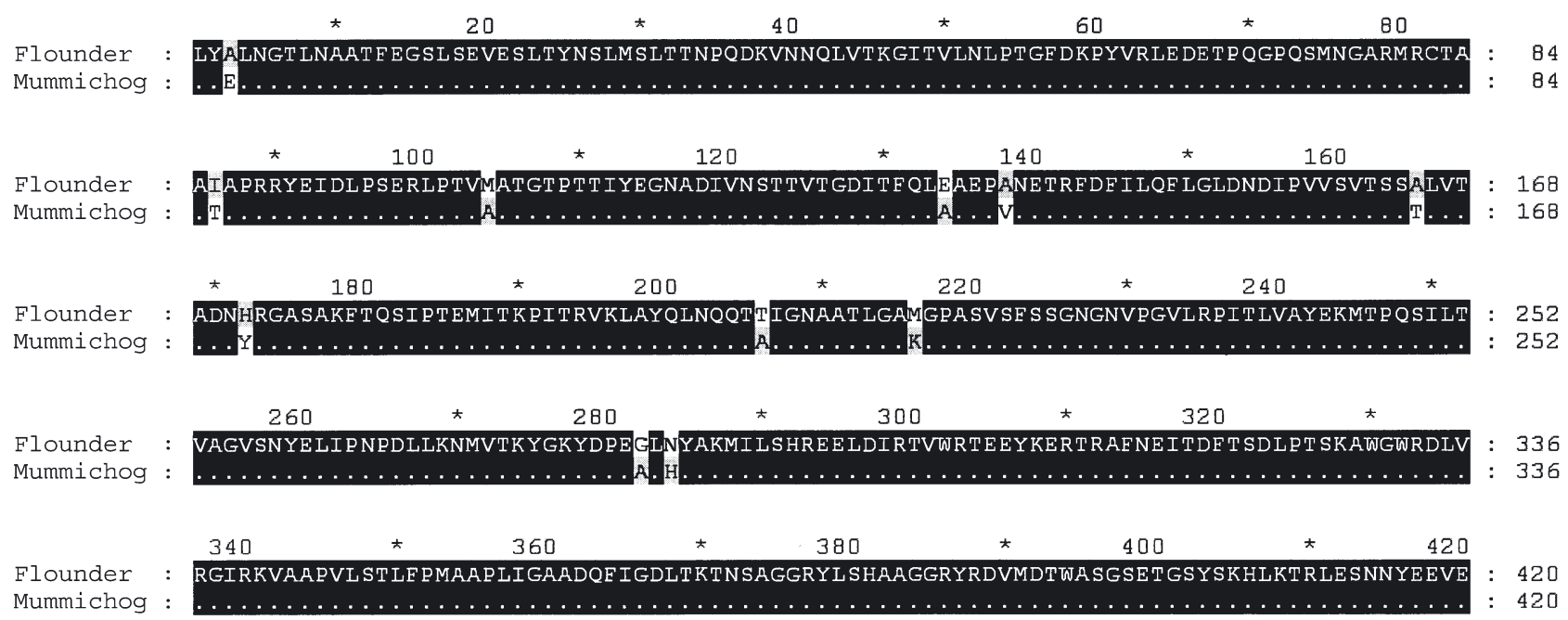

Flounder : LPKPTKE : 427

Mummichog : .....: $: 427$

Fig. 4. Comparison of partial deduced amino acid sequences of aquabirnaviruses isolated from flounder Pseudopleuronectes americanus and mummichog Fundulus heteroclitus. * : every 10th amino acid 
Table 1. Pairwise distances of flounder Pseudopleuronectes americanus, mummichog Fundulus heteroclitus, and type strains of aquabirnavirus Serogroup A based on deduced amino acid sequences of a 427 amino acid sequence within the VP2 protein. Flndr $=$ flounder isolate; Mum = mummichog isolate; $\mathrm{WB}=$ West Buxton strain $; \mathrm{JA}=$ Jasper strain $; \mathrm{Sp}=\mathrm{Sp}$ strain; $\mathrm{Ab}=\mathrm{Ab}$ strain; $\mathrm{He}=$ Hecht strain; $\mathrm{Te}=$ Telina strain; $\mathrm{C} 1=$ Canada 1 strain; $\mathrm{C} 2=$ Canada 2 strain; $\mathrm{C} 3=$ Canada 3 strain

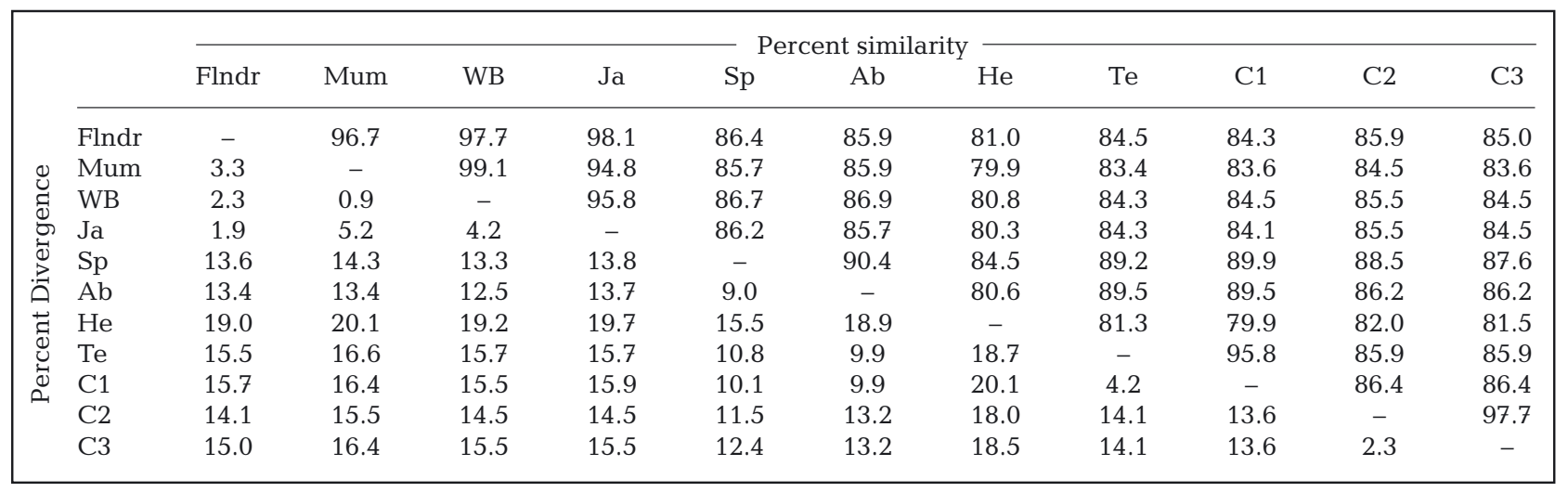

WB and Jasper strains can be distinguished by a difference in reaction with only a single monoclonal antibody (Caswell-Reno et al. 1989). Nevertheless, it is interesting that a possible member of the Jasper serotype was isolated from a marine fish species in the Chesapeake Bay, considering that this serotype has been confined to a small region in the Rocky Mountains of Canada. Also interesting is the fact that, while closely related, the viruses isolated from flounder and mummichog in the Chesapeake Bay are not identical (96.7\% similarity in deduced amino acid sequence). These data demonstrate that different strains of aquabirnaviruses can be present in different species in the same geographical area.

Aquabirnaviruses have been detected in a great diversity of marine fish worldwide (Essbauer \& Ahne 2001). However, the species Fundulus heteroclitus and Pseudopleuronectes americanus are new reported hosts for aquabirnaviruses in the Chesapeake Bay. The only other report on the presence of an aquabirnavirus in the Chesapeake Bay was an isolate from Atlantic menhaden Brevortia tyrannus (Stephens et al. 1980). McAllister et al. (1984) reported isolation of an aquabirnavirus from Southern flounder Paralichthys lethostigma in the Pamlico River estuary in North Carolina (USA). The flounder $P$. americanus specimen investigated in this study was asymptomatic. Interestingly, this fish, while simultaneously infected with an aquabirnavirus, exhibited aquabirnavirus-specific neutralizing antibodies of titers up to $1: 2560$. This may explain the asymptomatic, carrier state of the fish.

The mummichog specimens used in this investigation also were asymptomatic for aquabirnaviruses. However, these were collected from a polycyclic aromatic hydrocarbon (PAH)-contaminated site in the Chesapeake Bay, and had severe liver tumors and proved to be immuno-compromised (Vogelbein et al. 1990). This is the first report of the detection of an aquabirnavirus in mummichog Fundulus heteroclitus. Additional studies are needed to determine the prevalence, in general, and the prevalence of specific genotypes and serotypes of aquabirnaviruses in various marine species in the Chesapeake Bay.

Acknowledgements. This work was supported by grants from the NOAA Sea Grant Program (R/FMD-269) and the Maine Agricultural and Forestry Experiment Station. This is Maine Agricultural and Forestry Experiment Station Publication No. 2633. We thank M. Faisal and W. Vogelbein, Virginia Institute of Marine Science, Gloucester Point, Virginia, USA, for scientific and technical support.

\section{LITERATURE CITED}

Blake S, Ma JY, Caporale DA, Jairath S, Nicholson BL (2001) Phlyogenetic relationships of aquatic birnaviruses based on deduced amino acid sequences of genome segment $\mathrm{A}$ cDNA. Dis Aquat Org 45:89-102

Caswell-Reno P, Lipipun V, Reno PW, Nicholson BL (1989) Utilization of a group reactive and other monoclonal antibodies in an enzyme immunodot assay for identification and presumptive serotyping of aquatic birnaviruses. J Clin Microbiol 27:1924-1929

Christie KE, Havarstein LS, Djupvik HO, Ness S, Endresen C (1988) Characterization of a new serotype of infectious pancreatic necrosis virus isolated from Atlantic salmon. Arch Virol 103:167-177

Christie KE, Ness S, Djupvik HO (1990) Infectious pancreatic necrosis virus in Norway: partial serotyping by monoclonal antibodies. J Fish Dis 13:323-327

Cohen J, Poinsard A, Scherrer R (1973) Physical, chemical and morphological features of infectious pancreatic necrosis virus. J Gen Virol 21:485-498

Dobos P, Roberts TE (1983) The molecular biology of infectious pancreatic necrosis virus: a review. Can J Microbiol 29:377-384 
Dobos P, Hill BJ, Hallett R, Kells DTC, Becht H, Teninges D (1979) Biophysical and biochemical characterization of five animal viruses with bisegmented double-stranded RNA genomes. J Virol 32:593-605

Duncan R, Dobos P (1986) The nucleotide sequence of infectious pancreatic necrosis virus (IPNV) dsRNA A segment reveals one large ORF encoding a precursor protein. Nucleic Acids Res 14:5934-5935

Duncan R, Nagy E, Krell PJ, Dobos P (1987) Synthesis of the infectious pancreatic necrosis virus polyprotein, detection of a virus-encoded protease, and fine structure mapping of genome segment A coding regions. J Virol 61:3655-3664

Essbauer S, Ahne W (2001) Viruses of lower vertebrates. J Vet Med B 48:403-475

Havarstein LS, Kalland KH, Christie KE, Endresen C (1990) Sequence of the large double-stranded RNA segment of the N1 strain of infectious pancreatic necrosis virus: a comparison with other Birnaviridae. J Gen Virol 71:299-308

Hill BJ (1982) Infectious pancreatic necrosis virus and its virulence. In: Roberts RJ (ed) Microbial disease of fish. Academic Press, London, p 91-114

Hill BJ, Way K (1995) Serological classification of infectious pancreatic necrosis (IPN) virus and other aquatic birnaviruses. Annu Rev Fish Dis 5:55-78

Kusuda R, Kado K, Takeuchi Y, Kawai K, (1989) Characteristics of two virus strains isolated from young Japanese flounder Paralichthys olivaceus. Suisanzoshoku 37: $115-120$

MacDonald RD, Yamamoto $\mathrm{T}$ (1977) The structure of infectious pancreatic necrosis virus RNA. J Gen Virol 34: 235-247

Mahy BWJ, Kangro HO (1996) Virology methods manual. Academic Press, London

Editorial responsibility: Jo-Ann Leong,

Kaneohe, Hawaii, USA
McAllister PE, Newman WW, Sauber JH, Owens WJ (1984) Isolation of infectious pancreatic necrosis virus (serotype $\mathrm{Ab}$ ) from diverse species of estuarine fish. Helgol Meeresunters 37:317-328

Mortensen HF, Heuer OE, Lorenzen N, Otte L, Olesen NJ (1999) Isolation of viral haemorrhagic septicaemia virus (VHSV) from wild marine fish species in the Baltic Sea, Kattegat, Skagerrak and the North Sea. Virus Res 63: 95-106

Munday BL, Owens L (1998) Viral diseases of fish and shellfish in Australian mariculture. Fish Pathol 33:193-200

Nicholson BL (1993) Use of monoclonal antibodies in fish disease research. Annu Rev Fish Dis 3:241-257

Sano T, Fukuda H (1987) Principal microbial diseases of mariculture in Japan. Aquaculture 67:53-58

Sohn SG, Park MA, Do JW, Choi JY, Park JW (1995) Birnavirus isolated from cultured flounder in Korea. Fish Pathol 30:279-280

Sorimachi M, Hara T (1985) Characteristics and pathogenicity of a virus isolated from yellowtail fingerlings showing ascites. Fish Pathol 19:231-238

Stephens EB, Nedsman MW, Zachary AL, Hetrick FM (1980) A viral aetiology for the annual spring epizootics in Atlantic menhaden, Brevoortia tyrannus, in the Chesapeake Bay. J Fish Dis 3:387-399

Vogelbein W, Fournie JW, Van Feld PA, Hengst RJ (1990) Hepatic neoplasms in the mummichog Fundulus heteroclitus from a creosote-contaminated site. Cancer Res 50: 5978-5986

Wolf K (1988) Fish viruses and fish viral diseases. Cornell University Press, Ithaca, NY

Wolf K, Quimby MC (1962) Established eurythermic line of fish cells in vitro. Science 135:1065-1066

Submitted: June 15, 2002; Accepted: June 12, 2003

Proofs received from author(s): August 22, 2003 